
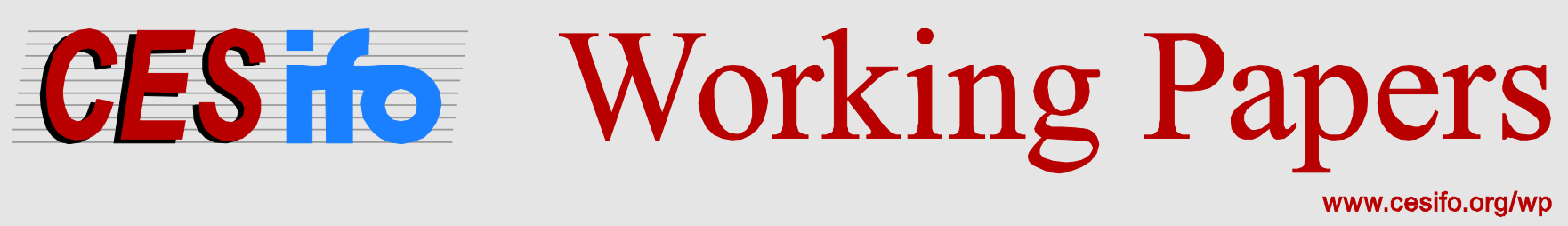

\title{
Student and Graduate Migration and its Effect on the Financing of Higher Education
}

\author{
Tina Haussen \\ Silke Uebelmesser
}

\section{CESIFO WORKING PAPER NO. 4963}

CATEgory 1: Public FinANCE

ORIGINAL VERSION: SEPTEMBER 2014

THIS VERSION: August 2015

Presented at CESifo Area Conference on Public Sector Economics, April 2014

An electronic version of the paper may be downloaded

- from the SSRN website:

- from the RePEc website:

- from the CESifo website:

WWW.SSRN.com

www.RePEc.org

www.CESifo-group.org/wp 


\title{
Student and Graduate Migration and its Effect on the Financing of Higher Education
}

\begin{abstract}
The number of international students worldwide has almost doubled in the last decade. In higher education systems that are partly tax-funded, a country's labour force might not be willing to subsidize the education of international students who might move away after graduation. This paper analyses how student migration affects governmental decisions regarding the financing of higher education for 22 OECD countries for the period of 2000 to 2011. Based on fixed effects estimations, we find a significant positive correlation between the share of international students and the private funding share for higher education. This result is robust to changes in the specification, including estimations for country groups and for an expanded lag structure. The use of an instrumental variable approach supports a causal interpretation.
\end{abstract}

JEL-Code: H520, F220, I220, I280.

Keywords: Higher education, financing, international student migration.

Tina Haussen

University of Jena

Carl-Zeiss-Str. 3

Germany-07743 Jena

tina.haussen@uni-jena.de
Silke Uebelmesser*

University of Jena

Carl-Zeiss-Str. 3

Germany-07743 Jena

silke.uebelmesser@uni-jena.de

*corresponding author

August 21, 2015

This is an updated version of the paper previously published as CESifo Working Paper in September 2014. The authors thank participants at the CESifo Public Sector Economics Conference in Munich, the IIPF Conference in Lugano, the CGDE Workshop in Leipzig and the JERW Seminar in Jena for helpful suggestions and comments. 


\section{Introduction}

In all OECD countries, higher education is financed by a mix of public contributions (e.g. income taxes levied on labour income) and private contributions (e.g. tuition fees paid by students). Often, the public share clearly dominates. However, within the last two decades almost half of the OECD countries have introduced or increased tuition fees. During the same period, the number of international students has risen rapidly. In 1990, 1.3 million students were enrolled outside their country of citizenship worldwide; this number was $60 \%$ higher in 2000, and increased more than threefold by 2011, when more than 4.3 million students were studying internationally - many of them in OECD countries (OECD 2013). The aim of the present paper is, first, to investigate whether and how the student and graduate migration affects governmental decisions about the financing of higher education and, second, to study other possible determinants of these governmental decisions.

In tertiary education systems that are partly publicly funded, there are two possible causal relationships between student migration and the financing of higher education. First, it may be that students are reacting to the institutional framework of higher education making it likely that the migration decisions of students are affected by cost considerations. Students take the extent of private contributions, e.g. tuition fees, into account. While comparably high public contributions may attract students from abroad, high tuition fees can prevent young people from studying in a foreign country. There is some empirical evidence in favour of this hypothesis, although the results are somewhat contradictory (e.g. Dwenger et al. 2012; Hübner 2012; Beine et al. 2014).

The contradictory state of research in this area motivates us to analyse whether the second causal link - namely, that student migration induces changes in governmental policies - may also be possible. This link is built on the following theoretical ideas: In tertiary education systems that are partly publicly funded, the country that "produces" human capital has to levy income taxes on the labour force to pay for the provision of higher education. Hence, the production principle applies (Gérard 2007). If students of one country (i.e. the home country) obtain tertiary education in another country (i.e. the host country), the labour force of the host country partly bears those international students' education costs. It is very likely that not all of those students will later pay for their education in the form of taxes, as many will leave the country after graduation. Students then free ride on the education system of the host country. If a large share of students - 
domestic or foreign - move abroad after graduation, this places a heavy financial burden on their former host country. Consequently, one might expect that different migration patterns of students and graduates affect the financing structure of higher education. Increasing student migration and low stay rates among graduates may force a government to shift financing more towards private contributions to ensure a sustainable financing system of tertiary education (Demange et al. 2014).

This idea is also motivated by the current political debate on whether and how to react to the large influx of international students into some OECD countries. As governments cannot be sure that all international students will stay in the host country after graduation, one way to reduce the costs of their education could be to impose fees on international students. Yet, this is not an option for all host countries. EU countries cannot charge different fees for domestic and foreign EU-citizen students, as this violates the nondiscrimination principle. However, there is no such restriction with respect to students from non-EU countries. Within the last decade, more and more EU countries decided to charge tuition fees for international, non-EU students. For example, Denmark charges no tuition fees for domestic students, but up to 16,000 Euro per year for non-EU students (OECD 2012). Similarly, in 2012, the Finnish parliament agreed to introduce tuition fees for non-EU students, on the grounds that Finnish taxpayers should not educate workers for non-EU Anglo-Saxon countries' economies. However, opinion was not unanimous on this decision - the law's opponents argued that being able to attract international students is an advantage for such a small country as Finland (European Commission 2012a). In contrast to Denmark and Finland, Germany and France have not reacted to the inflow of international students by demanding a larger private contribution from those students that they can discriminate against. In the face of this mixed anecdotal evidence, empirical analysis is needed to obtain a more comprehensive picture.

The present paper is organized as follows: Section 2 reviews the relevant empirical literature. Section 3 introduces the data from the regression analysis and some descriptive statistics, and Section 4 presents the estimation strategy that is used to evaluate the link between student migration and the financing of higher education. In Section 5, we provide our estimation results, which encompass not only the benchmark regressions, but also a number of robustness checks and instrumental variable regressions to address possible causality issues. Conclusions and final remarks are presented in Section 6 . 


\section{Related empirical literature}

Our paper combines two strands of empirical literature: the student migration literature and the education spending literature. First, we look at the student migration literature which analyses if student and graduate migration induces changes in governmental policies about higher education funding. To better understand the various additional factors that determine the financing of higher education, second, we look at the education spending literature, which analyses the socio-economic, political, and institutional determinants of overall and tertiary education spending.

To date, the student migration literature has generally used micro-level data from individual countries to determine whether the financing structure (in particular the size of the fees students must pay for higher education) is a determinant of student migration. Hübner (2012) explores whether the introduction of tuition fees in some but not all German federal states determined enrolment probabilities in Germany. Using this natural experiment, Hübner finds a significantly reduced probability of enrolment in those federal states that charge tuition fees.1 Similarly, Bruckmeier et al. (2013) investigate the effects of tuition fees on enrolment of first-year students at German public universities, taking the distance between a fee-charging university and the nearest fee-free alternative into account. They find lower enrolment at universities that both charged tuition fees and were located close to no fee universities. This decreased enrolment was twice as large as the decrease for fee-charging universities that were located further away from fee-free universities. Beine et al. (2014) aim to identify the most important factors influencing student migration to 14 OECD countries between 2004 and 2007. However, unlike Hübner (2012) and Bruckmeier et al. (2013), Beine et al. (2014) find a significant positive relationship between charging higher fees and attracting international students. Since students would not logically prefer higher fees to lower fees if universities were otherwise identical, Beine et al. (2014) hypothesize that students interpret fees as a sign of quality.

These - somewhat - ambiguous results point towards the possibility of a second causal effect. While students may react to the financing structure of higher education by engaging in more migration, it may, conversely, also be true that greater student and graduate migration may lead to higher private contributions for higher education. The first part of

\footnotetext{
1 Based on administrative data from applicants to medical schools in Germany, Dwenger et al. (2012) also find a small but significant effect of tuition fees on the probability that a student will apply to a university in his or her home state.
} 
our analysis focuses on this second possible causal effect.

To our knowledge, the education spending literature contains no studies on what determines the public versus private share of higher education funding. Rather, this body of literature investigates overall and tertiary public and private education spending and the contributing economic, institutional, political, and socio-economic factors.

With regard to economic factors, there is some evidence that GDP per capita, as an indicator of economic development, is positively associated with the percentage of GDP spent on public education (Busemeyer 2007). Tandberg (2010), however, whose focus is the determinants of state spending on higher education in the United States, relative to total state spending, finds a negative significant relationship between the gross state product per capita and relative state spending on higher education. Although Wagner's Law suggests that there is a positive relationship between economic development and public spending, it may be that this spending is not evenly allocated in this case, but is relatively higher in other public areas, such as health care (Tandberg 2010). When looking at the change of per capita income, Potrafke (2011a) finds a negative relation.

Partisan theory suggests that left-wing parties (e.g. social democrats) tend to increase total public spending on education, while right-wing parties (e.g. conservatives) make more intensive use of private alternatives. Left-wing parties that aim at maximizing redistribution of wealth usually have constituencies largely drawn from working-class and low-income voters. By contrast, the electoral base of right-wing parties is typically located in the middle and upper income classes, who are interested in minimizing tax contributions (see, e.g. Boix 1997; Busemeyer 2009). However, there is evidence that political parties may have diverse incentives to spend public money on different education levels. For example, Kauder and Potrafke (2013) use the introduction and subsequent incremental abolishment of tuition fees in some German federal states to examine how government ideology influences tuition fee policies. In line with partisan theory, they find that right-wing governments actively introduced tuition fees, while left-wing parties abolished existing tuition fees.

In the second part of our analysis, we build on the education spending literature, enlarging our analysis to explain how fiscal, political-economy, and other factors as additional variables to explain the share of private contributions to higher education spending. 


\section{Data}

The empirical analysis focuses on 22 OECD countries for the time period 2000-2011. Unless otherwise stated, all data are taken from the Education at a Glance publications (OECD 2001-2014). A more detailed description of all variables and their sources is available in Tables A.1 and A.2 in the Appendix.

\subsection{Expenditure on higher education}

Our dependent variable is the private funding of tertiary education as a share of total (i.e. private and public combined) funding. While public funding still constitutes the dominant source of funding in most OECD countries, private funding sources are becoming increasingly prominent.

Figure 1 illustrates country averages of the private financing share from 2000 to 2011 . The share of private expenditure on tertiary education is lowest in the Nordic countries, and highest in the Anglo-Saxon countries and in Japan. Figure 1 also displays the minimum and maximum levels of the private funding share for each country between 2000 and 2011 . All countries exhibit variation over time in their private higher education funding. In some countries, the private share varies markedly; one such example is the United Kingdom, where the relative share of private funding changed by more than 46 percentage points. This also holds - albeit to a smaller extent - for Portugal (30 percentage points), the Slovak Republic (23 percentage points), the United States (13 percentage points), Italy (12 percentage points), and Austria (11 percentage points).$^{2}$

\footnotetext{
2 The change may also be due to rising tuition fees for non-EU students. In our regression analysis, we
} will take into account the share of incoming students who can be discriminated against. 
Figure 1: Share of private expenditure on tertiary education (2000-2011)

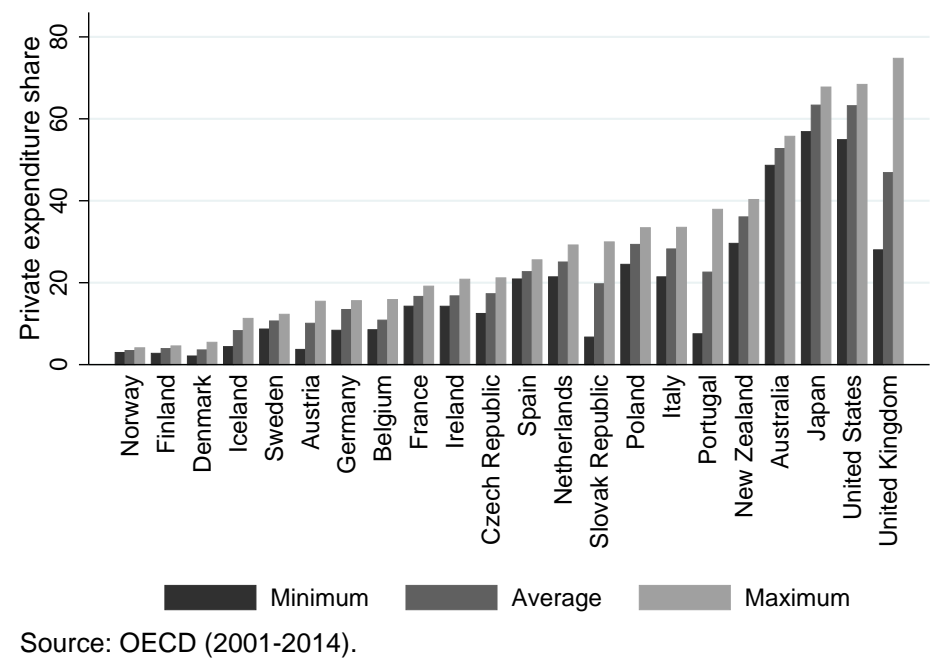

Our dependent variable has the shortcoming that it does not display the absolute level of monetary expenses per student. For example, in 2010, Australia's private share was $53.5 \%$ of the overall expenditure of 15,142 USD per student; while Austria had a similar overall expenditure per student (15,007 USD), with the private share equalling only $12.2 \%$. To correct for this, one of our control variables will be the total annual expenditure for higher education as a percentage of GDP.

\subsection{Student immigration}

Our main independent variable refers to student migration. Country-level data on the share of international students among the total number of students come from the UNESCOOECD-Eurostat (UOE) data collection on education statistics, which provides online data on the number of students enrolled outside their country of birth or citizenship since 1998 . Information is available about student migration from roughly 230 countries to individual OECD countries. In studying this, one must be careful in how the term international student is defined. Until 2003, most countries reported the number of international students based on their citizenship. However, this definition not only encompasses students that migrate for education reasons, but also those who moved to another country before studying (e.g. for family reasons) without changing their citizenship. In 2004, the UOE agreed to define students as international students only if they migrated solely for the 
purpose of education $3^{3}$ We start our analysis from the year 2000, which is why we use data based on citizenship to classify students as international. We think that this is an acceptable methodological choice, as in our sample there is a strong correlation (0.90) between the shares of international students based on the two different definitions.

In Figure 2, the minima, maxima, and average shares of international students are displayed for each country. Again, the Anglo-Saxon countries, Australia, New Zealand, and the United Kingdom, but also Austria have the highest shares of international students among their tertiary enrolees, with an average share of more than 19\%. Those countries - in addition to Ireland and the Czech Republic - also record the largest changes in the share of international students within the period of 2000 to 2011.

Figure 2: Share of international students among the total number of students (2000-2011)

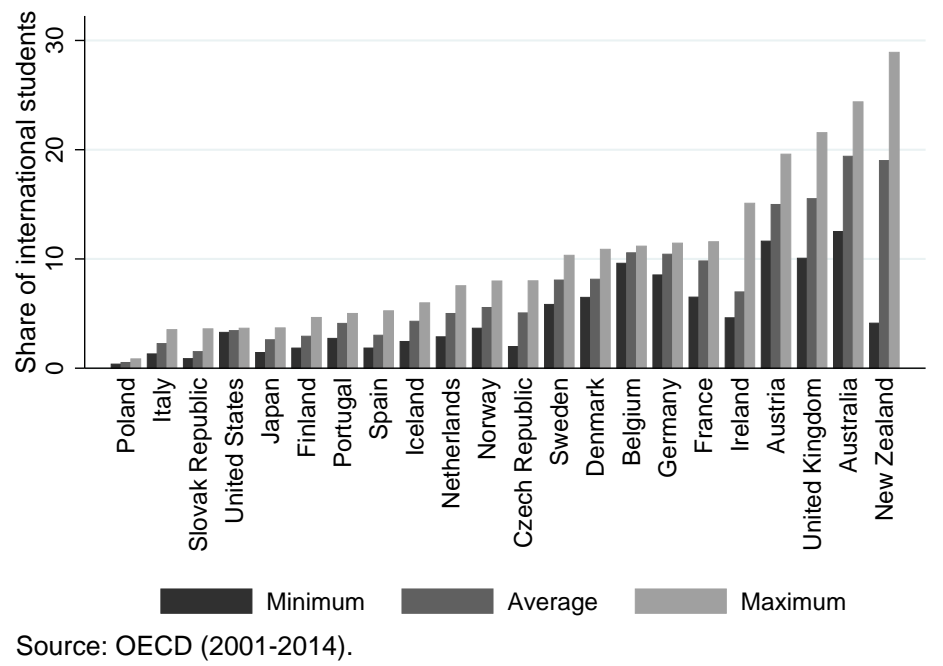

In most countries, national policies regulate tuition fees charged by public higher education institutions, as well as how these fees may differ between non-national students from different home countries. The most prominent example is EU countries, which are governed by the principle of non-discrimination, which forbids charging higher tuition fees for nonnational students from other EU countries. However, EU countries are free to charge higher tuition fees for non-EU students, and in 2011, 10 out of the $16 \mathrm{EU}$ countries in our sample did so.4 Non-EU countries can discriminate against any international students, so long as there are no bilateral or multilateral agreements in place that impose different

3 If destination countries report data on international students, they do so either based on residence status (since international students usually are not permanent residents of the country they study in) or when students acquired education prior to their studies outside the reporting country.

4 The 10 countries are Austria, Belgium, the Czech Republic, Denmark, Estonia, Ireland, the Netherlands, Poland, Sweden, and the United Kingdom (OECD 2013). 
rules $5^{5}$ Countries that are not governed by the principle of non-discrimination have widely varying policies: Norway does not discriminate between national and international students in public institutions, charging no fees for either group, while Australia, New Zealand, Japan, and the United States charge higher tuition fees for all international students. To account for these differences, we will split the share of international students into two groups as a robustness check: one group will consist of international students that can be discriminated against, and the other group will consist of international students that, due to policy regulations, cannot be discriminated against.

To obtain a first impression of the correlation between student immigration and the private funding share of higher education, we look at the simple correlation between the two variables. Panel (a) of Figure 3 displays average values for each of the 22 countries over the 12-year period. In Panel (b), the raw panel data are plotted. The graphs indicate a weak positive correlation between the share of international students and private funding of higher education. However, in Panel (a), the correlation is based on cross-country variation, with the Anglo-Saxon countries, the United Kingdom, Australia, and New Zealand, as the likely drivers. Japan and the United States are outliers in this respect, as they are characterized by a high private funding share but a modest immigration share. Panel (b) looks at variation both between and within countries. As we are interested in identifying the within-country effects of student immigration on the private financing share, we will use fixed effects estimations to exploit the panel structure of our data and to control for several factors that are likely to affect the private funding share. Estimations of subgroups of countries will help us to test the robustness of the regression results.

\footnotetext{
5 As an example, see the bilateral agreement between New Zealand and Australia, according to which students from New Zealand who study in Australia, as well as students from Australia who study in New Zealand, are both eligible to apply for Commonwealth-supported places (OECD 2012).
} 
Figure 3: Correlation between the private funding share and the share of international students

(a) Average values (2000-2011)

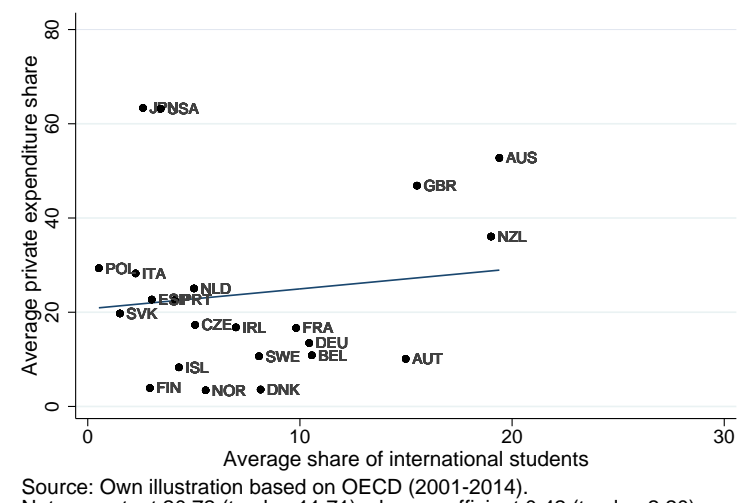

Source: Own illustration based on OECD (2001-2014).
Note: constant 20.72 (t-value 11.71), slope coefficient 0.42 (t-value 2.20). (b) Panel data (2000-2011)

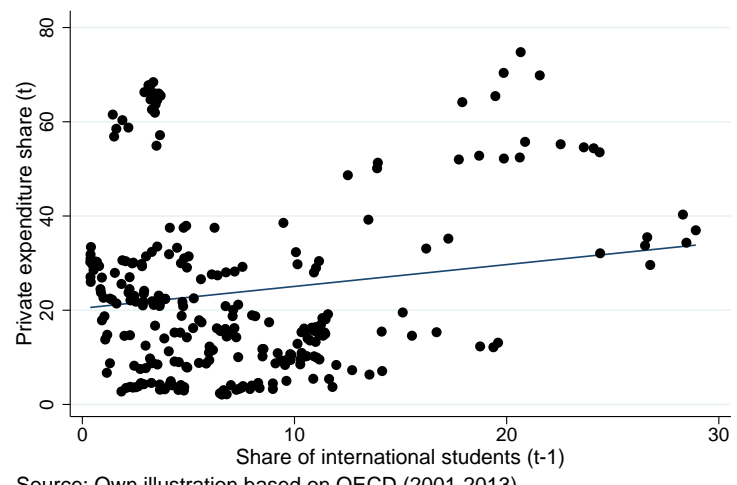

Source: Own illustration based on OECD (2001-2013).

Note: constant 20.42 (t-value 11.44), slope coefficient 0.46 (t-value 2.49 ).

\subsection{Further data}

As mentioned in Section 1, the more a country finances higher education via taxes paid by the labour force, the more it should be interested not only in the number of international students, but also in how likely it is that they will stay after graduation. Empirical evidence for the link between student and graduate migration is mixed: while some studies show a positive link between student immigration and the subsequent number of tertiary-educated international workers in that country (see, e.g. Dreher and Poutvaara 2011; Felbermayr and Reczkowski 2014), other studies provide evidence that graduates who have migrated before (e.g. for their education) are more likely to change their country of residence thereafter (i.e. to seek work in another country after graduation) (see, e.g. Parey and Waldinger 2011). As there are no panel data available on the number of international graduates that stay in their host country as job-holders, we use the employment rate of tertiary-educated individuals in the host country as a proxy, as this can be expected to represent the labour market conditions students face after graduation. The employment rate of tertiary-educated immigrants cannot be used due to data unavailability. We are 
aware of the limitations of this variable, such as failing to reflect potential discrimination $\sqrt{6}$

The empirical literature on the determinants of education spending guides our choice of further control variables. Since this literature usually concentrates on overall education, we only use those fiscal, political, and institutional variables which may be connected to tertiary education and which may explain the share (as opposed to the absolute value) of public and private contributions. First, we control for tax revenue (excluding social security funds) as a percentage of GDP. Since the source of the public funding share is mainly tax revenue, it seems plausible that a comparably larger tax revenue would allow policy makers to provide more public funding for education. In contrast, a relatively smaller tax revenue might reduce a government's ability to publicly finance tertiary education, and instead induce a shift to more private-based funding. In line with this argumentation, we also include a country's GDP in our regression.7 As economies grow, we expect policy makers to anticipate that they will have more public funds available; hence, we expect a negative relationship between GDP (growth) and changes in the share of private funding (Busemeyer 2007).

Second, we take into account political-economic variables such as the ruling party's ideology and the demographic structure of the electorate. As stated in Section 2, there is a broad consensus in the literature that government ideology influences the composition and allocation of the public budget (e.g. Potrafke 2011b, Kauder and Potrafke 2013). We therefore control for the share of parliamentary seats held by right-wing parties among all governmental parties, weighted by the number of days the government was in office in a given year. Data are taken from Armington et al. (2012). Following the political-economic literature on intergenerational conflicts over the provision of education (see e.g. Poterba 1998; Ladd and Murray 2001), different age compositions of a given population may place distinct pressures on the public education budget. It is expected that as a society

6 Based on results of the economic literature, we tested several plausible proxy variables in our regression analysis. One is the share of highly skilled immigrants among the population (taken from Docquier and Marfouk 2006). This idea is based on the findings of Dreher and Poutvaara (2011) and Felbermayr and Reczkowski (2014). Another is the internal rate of return to higher education. This proxy is based on work by Bratsberg (1995) and Rosenzweig (2008), who found that international students in the US are less likely to stay in their host country if the return on education in the home country is higher than that in the host country. However, both the share of highly skilled immigrants and the internal rate of return on higher education are only available for, at most, a few points in time, so we cannot use them in a fixed effects regression.

7 The correlation between GDP and the number of students is 0.988 , between GDP and the size of the population is 0.983 , and between the number of students and the size of the population is 0.968 . To avoid multicollinearity, we only include GDP; we obtain similar regression results if, instead, we include one of the other two variables. 
ages, support for programs that target young people such as public education decreases, while support for programs that benefit older people, like public health care or pensions, increases. To control for this effect, we include the old-age dependency ratio, defined as the proportion of people older than 65 relative to those aged 20 to 64 .

Third, we pay attention to the type of higher education institutions in each country. In the majority of the countries in our sample, tertiary education is controlled and managed by public authorities. However, in some countries (e.g. Japan, the Netherlands, the United Kingdom, and the United States), a significant share of students is enrolled in private higher education institutions, i.e. in institutions that are controlled by non-governmental, private entities. As this private status enables universities to make financial decisions independently from the government, we will use the proportion of total students who are enrolled in private higher education institutions as a further control variable.

\section{Estimation strategy}

To evaluate the relationship between student migration and the private funding share of higher education, we use a panel of aggregated data representing 22 OECD countries for the years 2000 to 2011. As we assume the private financing share to be determined by the share of international students and other variables, we lag the independent variables by one year. We therefore estimate the following fixed effects equation:

$$
\operatorname{PrivExpend}_{i, t}=\alpha_{i}+\beta_{1} \text { InternationalStudents }_{i, t-1}+\beta_{2} X_{i, t-1}+u_{i, t}
$$

with countries $i=1, \ldots, 22$ and time periods $t=2000,2001, \ldots, 2011 . u_{i, t}$ is the normally distributed error term. Our dependent variable "PrivExpend ${ }_{i, t}$ " denotes the private funding share of higher education of country $i$ in year $t$. Our main explanatory variable, "InternationalStudents ${ }_{i, t-1}$ ", is the share of students who immigrated to country $i$ in year $t-1$ among its total number of students. " $X_{i, t-1}$ " is a vector of control variables for country $i$ in year $t-1$, which may affect the private funding share as described in Section 3$]^{8}$ The regression includes a country-specific, time-invariant intercept $\alpha_{i}$ to address unobserved heterogeneity.

\footnotetext{
8 Since total expenditure per student is included here to control for the different total expenditure levels, it is not lagged.
} 


\section{Results}

The estimation results for the fixed effects models are presented first. The baseline estimations are followed by robustness checks to account for possible country-group effects and to allow for changes in the lag structure. We then address the issue of reverse causality and perform instrumental-variable regressions to identify the underlying causal relationship.

\subsection{Benchmark regressions}

The first set of estimations includes seven models where we subsequently add control variables to see how the other coefficients respond (Table 1). As we are aware of the possible endogeneity problem that arises from the loop of causality between the private financing share (dependent variable) and the share of international students (independent variable), we will first cautiously interpret our regression results as correlations. In Section 5.3, we present additional evidence that supports a causal interpretation. Without adding any further control variables, the regression analysis yields a positive and significant correlation at the $1 \%$ level between the share of international students and the share of private expenditure on higher education (Model (1)). This correlation may indicate that a larger share of international students among the total number of students in a country, leads to a larger private funding share. The coefficient of the employment rate of tertiary-educated workers (our proxy for the stay rate of graduates) is negative and highly significant. This may be in line with our hypothesis that positive developments on the labour market make highly educated graduates more likely to stay, producing taxable income that should in turn lead to a decrease in the share of private funding for higher education.

In Models (2) and (3), we then add a country's tax revenue (excluding social security funds) and GDP. The coefficients of the share of international students and the employment rate of tertiary-educated graduates are similar in both size and significance. Although the negative coefficient of tax revenue may suggest that higher tax revenues lead to more financial scope to publicly fund education, it remains insignificant throughout our baseline regressions. GDP is positively and significantly related to the private financing share of higher education. This finding is in line with the findings of Tandberg (2010), who argues that countries might invest relatively more in public areas other than education as their 
economy grows.

Table 1: Determinants of private higher education spending - benchmark regression

\begin{tabular}{|c|c|c|c|c|c|c|c|}
\hline DV: Private expenditure share & (1) & (2) & (3) & (4) & (5) & (6) & (7) \\
\hline Share of international students & $\begin{array}{l}0.551^{* * *} \\
(0.133)\end{array}$ & $\begin{array}{c}0.545^{* * *} \\
(0.134)\end{array}$ & $\begin{array}{c}0.533^{* * *} \\
(0.133)\end{array}$ & $\begin{array}{c}0.531^{* * *} \\
(0.133)\end{array}$ & $\begin{array}{c}0.498^{* * *} \\
(0.132)\end{array}$ & $\begin{array}{c}0.509^{* * *} \\
(0.135)\end{array}$ & \\
\hline Share of non-discriminable int. students & & & & & & & $\begin{array}{c}0.741^{*} \\
(0.383)\end{array}$ \\
\hline Share of discriminable int. students & & & & & & & $\begin{array}{l}0.480^{* * *} \\
(0.153)\end{array}$ \\
\hline Employment rate tertiary educated & $\begin{array}{c}-1.173^{* * *} \\
(0.241)\end{array}$ & $\begin{array}{c}-1.136^{* * *} \\
(0.254)\end{array}$ & $\begin{array}{c}-1.114^{* * *} \\
(0.252)\end{array}$ & $\begin{array}{c}-1.121^{* * *} \\
(0.253)\end{array}$ & $\begin{array}{c}-1.204^{* * *} \\
(0.253)\end{array}$ & $\begin{array}{c}-1.207^{* * *} \\
(0.253)\end{array}$ & $\begin{array}{c}-1.176^{* * *} \\
(0.279)\end{array}$ \\
\hline Total expenditure (in \% of GDP) & $\begin{array}{c}0.143 \\
(0.189)\end{array}$ & $\begin{array}{c}0.139 \\
(0.189)\end{array}$ & $\begin{array}{c}0.075 \\
(0.190)\end{array}$ & $\begin{array}{c}0.082 \\
(0.191)\end{array}$ & $\begin{array}{c}-0.002 \\
(0.192)\end{array}$ & $\begin{array}{c}0.004 \\
(0.193)\end{array}$ & $\begin{array}{c}0.082 \\
(0.215)\end{array}$ \\
\hline Tax revenue (in \% of GDP) & & $\begin{array}{c}-0.129 \\
(0.277)\end{array}$ & $\begin{array}{c}-0.057 \\
(0.277)\end{array}$ & $\begin{array}{c}-0.061 \\
(0.277)\end{array}$ & $\begin{array}{c}0.009 \\
(0.276)\end{array}$ & $\begin{array}{c}0.007 \\
(0.276)\end{array}$ & $\begin{array}{c}0.126 \\
(0.294)\end{array}$ \\
\hline GDP & & & $\begin{array}{c}0.175^{* *} \\
(0.077)\end{array}$ & $\begin{array}{c}0.172^{* *} \\
(0.077)\end{array}$ & $\begin{array}{c}0.129 \\
(0.079)\end{array}$ & $\begin{array}{c}0.129 \\
(0.079)\end{array}$ & $\begin{array}{l}0.176^{* *} \\
(0.089)\end{array}$ \\
\hline Right-wing parties (seat share) & & & & $\begin{array}{c}0.005 \\
(0.011)\end{array}$ & $\begin{array}{c}0.006 \\
(0.011)\end{array}$ & $\begin{array}{c}0.006 \\
(0.011)\end{array}$ & $\begin{array}{c}0.001 \\
(0.012)\end{array}$ \\
\hline Old-age dependency ratio & & & & & $\begin{array}{l}0.664^{* *} \\
(0.271)\end{array}$ & $\begin{array}{c}0.680^{* *} \\
(0.274)\end{array}$ & $\begin{array}{c}0.583^{*} \\
(0.318)\end{array}$ \\
\hline $\begin{array}{l}\text { Share of students enrolled } \\
\text { in private universities }\end{array}$ & & & & & & $\begin{array}{c}-0.031 \\
(0.077)\end{array}$ & $\begin{array}{c}-0.036 \\
(0.100)\end{array}$ \\
\hline Constant & $\begin{array}{l}117.608^{* * *} \\
(20.804)\end{array}$ & $\begin{array}{l}117.995^{* * *} \\
(20.854)\end{array}$ & $\begin{array}{l}112.768^{* * *} \\
(20.800)\end{array}$ & $\begin{array}{l}113.219^{* * *} \\
(20.857)\end{array}$ & $\begin{array}{l}103.746^{* * *} \\
(20.997)\end{array}$ & $\begin{array}{l}104.319 * * * \\
(21.082)\end{array}$ & $\begin{array}{l}99.211^{* * *} \\
(22.814)\end{array}$ \\
\hline Observations & 264 & 264 & 264 & 264 & 264 & 264 & 242 \\
\hline No. of countries & 22 & 22 & 22 & 22 & 22 & 22 & 22 \\
\hline $\log ($ likelihood) & -797.224 & -797.104 & -794.243 & -794.121 & -790.788 & -790.694 & -722.723 \\
\hline
\end{tabular}

Notes: All variables are lagged by one year except the total expenditure for tertiary education in \% of GDP. Standard errors in parentheses *** $\mathrm{p}<0.01,{ }^{* *} \mathrm{p}<0.05, * \mathrm{p}<0.1$. Variable description in Tables A.1 and A.2

In Models (4) and (5), we include political-economic variables that have proven to be important in determining spending on education. We do not find any statistically significant relationship between the percentage of parliamentary seats occupied by right-wing parties and the private funding share of higher education.9 We do, however, find a positive and significant correlation between the old-age dependency ratio and the private funding share. In accordance with the political-economic literature on intergenerational conflicts over the provision of education (e.g. Poterba 1998; Ladd and Murray 2001), this correlation may suggest that an increase in the population of older adults leads to increased demand for public spending in areas such as health care and pensions; this, in turn, increases the need for more private spending on education.

The share of total students who were enrolled in private universities was not found to exert any significant effect on the private funding share of higher education (Model (6)).

To account for the fact that international students are not a homogeneous group when it

9 We also controlled for the percentage of parliamentary seats held by centrist and left-wing parties, the coefficients of which were both insignificant. Results can be provided upon request. 
comes to tuition discrimination, we split the proportion of international students into those who can and those who cannot be treated differently with regard to tuition (Model (7)). For both of these subgroups, the proportion of international students remained positively and significantly correlated with the proportion of private spending on higher education, with a greater significance for the group of students who can be charged higher tuition fees.

\subsection{Robustness checks}

\subsubsection{Country groups}

As argued in Sections 1 and 2, we expect a country's private funding share to increase with the share of international students, who might move away after graduation. However, the correlation between the share of international students and the share of private expenditure on higher education (see Figure 3) indicates that there are several groups of countries that differ from each other with respect to our main variables of interest. Figure 4 replicates Panel (b) of Figure 3 but highlights the data points from the Anglo-Saxon, Nordic and all other countries in our sample. Whereas the Anglo Saxon countries - in particular the United Kingdom, Australia and New Zealand - are characterized by high levels, but also large variations in their proportions of international students and their share of private funding, respectively, the Nordic countries face much smaller levels and variations of both variables.

Figure 4: Correlation between private funding and student immigration: Country groups

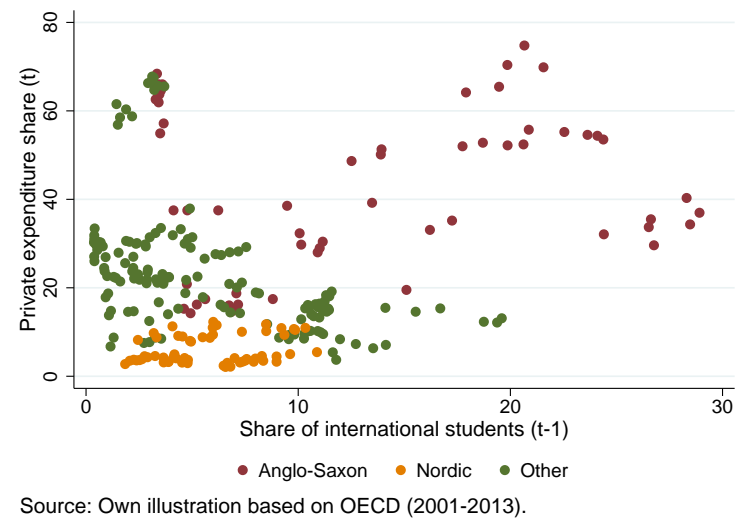

To account for these differences, in Models (8) and (9) in Table 2 , we re-run our specifications from Models (6) and (7) of Table 1, but drop the United Kingdom, Australia, and New 
Zealand from the sample. The magnitude of the coefficients of the student immigration shares decreases only slightly, but we lose some significance. When we split the proportion of international students, only the coefficient of the share of international students who cannot be discriminated against remains significant. The coefficients of our control variables remain qualitatively unchanged. Yet, the coefficient of GDP becomes insignificant. We then drop all Anglo-Saxon countries (Models (10) and (11)) and all Anglo-Saxon and all Nordic countries (Models (12) and (13)) from our sample. For all specifications, our main results do not change qualitatively, i.e., our results are not fully driven by specific country groups.

Table 2: Determinants of private higher education spending - country groups

\begin{tabular}{|c|c|c|c|c|c|c|}
\hline \multirow[t]{2}{*}{ DV: Private expenditure share } & \multicolumn{2}{|c|}{ w/o UK, AUS, NZL } & \multicolumn{2}{|c|}{ w/o Anglo-Saxon } & \multicolumn{2}{|c|}{ w/o Anglo-Saxon, Nordic } \\
\hline & (8) & (9) & $(10)$ & $(11)$ & $(12)$ & $(13)$ \\
\hline Share of international students & $\begin{array}{c}0.357^{*} \\
(0.208)\end{array}$ & & $\begin{array}{c}0.540^{* *} \\
(0.252)\end{array}$ & & $\begin{array}{c}0.676^{*} \\
(0.362)\end{array}$ & \\
\hline Share of non-discriminable int. students & & $\begin{array}{c}0.509^{*} \\
(0.276)\end{array}$ & & $\begin{array}{c}0.615^{* *} \\
(0.300)\end{array}$ & & $\begin{array}{c}0.678^{*} \\
(0.408)\end{array}$ \\
\hline Share of discriminable int. students & & $\begin{array}{c}0.230 \\
(0.257)\end{array}$ & & $\begin{array}{c}0.348 \\
(0.329)\end{array}$ & & $\begin{array}{c}0.602 \\
(0.539)\end{array}$ \\
\hline Employment rate tertiary educated & $\begin{array}{c}-0.816^{* * *} \\
(0.187)\end{array}$ & $\begin{array}{c}-0.811^{* * *} \\
(0.197)\end{array}$ & $\begin{array}{c}-0.901^{* * *} \\
(0.208)\end{array}$ & $\begin{array}{c}-0.897^{* * *} \\
(0.216)\end{array}$ & $\begin{array}{c}-1.059^{* * *} \\
(0.301)\end{array}$ & $\begin{array}{c}-1.097^{* * *} \\
(0.321)\end{array}$ \\
\hline Total expenditure (in \% of GDP) & $\begin{array}{c}0.320^{* *} \\
(0.162)\end{array}$ & $\begin{array}{c}0.255 \\
(0.168)\end{array}$ & $\begin{array}{c}0.305 \\
(0.185)\end{array}$ & $\begin{array}{c}0.194 \\
(0.189)\end{array}$ & $\begin{array}{c}0.281 \\
(0.245)\end{array}$ & $\begin{array}{c}0.128 \\
(0.252)\end{array}$ \\
\hline Tax revenue (in \% of GDP) & $\begin{array}{c}0.127 \\
(0.213)\end{array}$ & $\begin{array}{c}0.214 \\
(0.220)\end{array}$ & $\begin{array}{c}0.039 \\
(0.232)\end{array}$ & $\begin{array}{c}0.154 \\
(0.243)\end{array}$ & $\begin{array}{r}-0.197 \\
(0.389)\end{array}$ & $\begin{array}{c}0.023 \\
(0.404)\end{array}$ \\
\hline GDP & $\begin{array}{c}0.007 \\
(0.054)\end{array}$ & $\begin{array}{c}0.046 \\
(0.059)\end{array}$ & $\begin{array}{r}-0.003 \\
(0.222)\end{array}$ & $\begin{array}{c}0.147 \\
(0.249)\end{array}$ & $\begin{array}{r}-0.108 \\
(0.287)\end{array}$ & $\begin{array}{c}0.058 \\
(0.339)\end{array}$ \\
\hline Right-wing parties (seat share) & $\begin{array}{c}0.003 \\
(0.008)\end{array}$ & $\begin{array}{c}-0.000 \\
(0.009)\end{array}$ & $\begin{array}{c}0.006 \\
(0.009)\end{array}$ & $\begin{array}{c}0.000 \\
(0.010)\end{array}$ & $\begin{array}{c}0.011 \\
(0.014)\end{array}$ & $\begin{array}{c}0.002 \\
(0.014)\end{array}$ \\
\hline Old-age dependency ratio & $\begin{array}{l}0.897^{* * *} \\
(0.202)\end{array}$ & $\begin{array}{l}0.897^{* * *} \\
(0.221)\end{array}$ & $\begin{array}{l}0.832^{* * *} \\
(0.268)\end{array}$ & $\begin{array}{l}0.816^{* * *} \\
(0.290)\end{array}$ & $\begin{array}{l}0.982^{* * *} \\
(0.364)\end{array}$ & $\begin{array}{c}0.942^{* *} \\
(0.401)\end{array}$ \\
\hline $\begin{array}{l}\text { Share of students enrolled } \\
\text { in private universities }\end{array}$ & $\begin{array}{c}0.008 \\
(0.055)\end{array}$ & $\begin{array}{c}0.027 \\
(0.068)\end{array}$ & $\begin{array}{c}-0.019 \\
(0.058)\end{array}$ & $\begin{array}{c}0.009 \\
(0.071)\end{array}$ & $\begin{array}{c}-0.008 \\
(0.069)\end{array}$ & $\begin{array}{c}0.032 \\
(0.088)\end{array}$ \\
\hline Constant & $\begin{array}{l}56.906^{* * *} \\
(15.479) \\
\end{array}$ & $\begin{array}{l}54.445^{* * *} \\
(16.040) \\
\end{array}$ & $\begin{array}{l}65.324^{* * *} \\
(19.259) \\
\end{array}$ & $\begin{array}{l}62.721^{* * *} \\
(19.708) \\
\end{array}$ & $\begin{array}{l}84.447^{* * *} \\
(26.307)\end{array}$ & $\begin{array}{l}83.152^{* * *} \\
(28.288)\end{array}$ \\
\hline Observations & 228 & 209 & 204 & 187 & 144 & 132 \\
\hline No. of countries & 19 & 19 & 17 & 17 & 12 & 12 \\
\hline $\log ($ likelihood $)$ & -594.153 & -536.051 & -534.012 & -482.617 & -395.609 & -358.666 \\
\hline
\end{tabular}

Notes: All variables are lagged by one year except the total expenditure for tertiary education in \% of GDP. Standard errors in parentheses; ${ }^{* * *} \mathrm{p}<0.01,{ }^{* *} \mathrm{p}<0.05,{ }^{*} \mathrm{p}<0.1$. Variable description in Tables A.1 and A.2

When interpreting the results for the group of non-Anglo-Saxon and non-Nordic countries (Models (12) and (13)), it should be taken into account that, compared to the full sample, the countries of this group are much more heterogeneous. While we control for some important factors, we likely miss other factors that might be particularly relevant for the bilateral or multilateral relations among at least some countries of this group. The examples of France and Belgium (i.e. the Walloon region) as well as Germany and Austria, serve to illustrate this point. Both pairs of countries share a common language and 
common borders, have one country that is relatively larger, and have a smaller country that found a non-monetary way to deal with increased numbers of students from its larger neighbour. In 2007, Austria and Belgium introduced quotas for medical students from abroad. In particular, German and French medical students tend to move to Austria and Belgium, respectively, when they do not meet the admission requirements in their home countries. Those students are likely to return home after graduation, and therefore place a heavy financial burden on the Austrian and Belgian taxpayers ${ }^{10}$ With the implementation of this regulation, the relative proportion of students that can be discriminated against increases. As this is a discipline-specific discrimination, however, this cannot be taken into account in the present study due to data limitations. Further, focusing on small, relatively homogeneous sub-groups can lead to problems stemming from small sample sizes. In general, the reliability of the estimates should be expected to be larger for the full sample.

\subsubsection{Lag structure}

Although we incorporated a one-year lag to reflect the time needed to implement new education-related policies, it could be argued that one year is insufficient time for national parliaments to decide on changes in education policies in response to changes in the number of international students. To further investigate the relationship between student immigration and the private funding share of higher education, Table 3 displays up to five lags for our independent variables. These lags are given for both of our baseline specifications, with and without splitting the share of international students (Models (6) and (7), respectively). We will first look at Model (14), which has the share of international students as the main independent variable. A two-year lag reveals very similar results to a one-year lag: The coefficient of the student immigration share becomes slightly smaller, but remains significant at the $1 \%$ level. Considering the model with the split immigration share lagged by two years, we find that only the share of discriminable international students remains significant, while the share of non-discriminable international students becomes insignificant (Model (15)). When lagging the independent variables by three and four years, respectively, the coefficients decrease in size but are still significant at least at the $5 \%$ level (Models (16) to (19)). Only when lagging the variables by five years does the coefficient for student immigration share become insignificant. However, the coefficient

\footnotetext{
${ }^{10}$ Although this quota violates the principle of freedom of movement within the European Union, the European Commission decided not to commence legal proceedings against the two countries until the year 2016 (European Commission 2012b), to secure the functioning of the health-care system.
} 
of the share of discriminable international students remains significant at the $10 \%$ level (Model (21)). The main results thus prove to be robust even with variations of the lag structure.

Interestingly, the relative effect of the group of international students, which can be treated differently from the native students, increases. Some of the other control variables also become significant. With a lag of three years or more, we find a significant negative correlation between tax revenue and private funding. This result is in line with the idea that relatively high tax revenue increases a government's ability to publicly finance tertiary education, and therefore induces a shift away from private-based funding. The results of GDP found so far remain qualitatively unchanged for lags of up to three years; for lags greater than three years, the correlation becomes insignificant. Note, that increasing number of lags also leads to a smaller sample size which can lead to changes in the results.

Table 3: Determinants of private higher education spending - lags

\begin{tabular}{|c|c|c|c|c|c|c|c|c|}
\hline \multirow[t]{2}{*}{ DV: Private expenditure share } & \multicolumn{2}{|c|}{ Lag: 2 years } & \multicolumn{2}{|c|}{ Lag: 3 years } & \multicolumn{2}{|c|}{ Lag: 4 years } & \multicolumn{2}{|c|}{ Lag: 5 years } \\
\hline & $(14)$ & $(15)$ & $(16)$ & $(17)$ & $(18)$ & (19) & $(20)$ & $(21)$ \\
\hline Share of international students $(\mathrm{t}-\mathrm{i})$ & $\begin{array}{l}0.493^{* * *} \\
(0.137)\end{array}$ & & $\begin{array}{l}0.433^{* * *} \\
(0.132)\end{array}$ & & $\begin{array}{c}0.294^{* *} \\
(0.140)\end{array}$ & & $\begin{array}{c}0.230 \\
(0.147)\end{array}$ & \\
\hline Share of non-discriminable internat. students (t-i) & & $\begin{array}{c}0.481 \\
(0.412)\end{array}$ & & $\begin{array}{c}0.435 \\
(0.464)\end{array}$ & & $\begin{array}{c}0.303 \\
(0.537)\end{array}$ & & $\begin{array}{c}0.006 \\
(0.592)\end{array}$ \\
\hline Share of discriminable internat. students (t-i) & & $\begin{array}{l}0.406^{* * *} \\
(0.149)\end{array}$ & & $\begin{array}{c}0.385^{* *} \\
(0.154)\end{array}$ & & $\begin{array}{c}0.278^{*} \\
(0.157)\end{array}$ & & $\begin{array}{c}0.268^{*} \\
(0.154)\end{array}$ \\
\hline Employment rate tertiary educated (t-i) & $\begin{array}{c}-1.239^{* * *} \\
(0.301)\end{array}$ & $\begin{array}{c}-1.229^{* * *} \\
(0.318)\end{array}$ & $\begin{array}{c}-1.214^{* * *} \\
(0.317)\end{array}$ & $\begin{array}{c}-1.206^{* * *} \\
(0.354)\end{array}$ & $\begin{array}{c}-0.743^{* *} \\
(0.353)\end{array}$ & $\begin{array}{r}-0.655^{*} \\
(0.382)\end{array}$ & $\begin{array}{c}-0.466 \\
(0.387)\end{array}$ & $\begin{array}{c}-0.342 \\
(0.406)\end{array}$ \\
\hline Total expenditure (in \% of GDP) & $\begin{array}{c}2.182 \\
(2.162)\end{array}$ & $\begin{array}{l}9.995^{* * *} \\
(3.253)\end{array}$ & $\begin{array}{l}11.908^{* * *} \\
(3.124)\end{array}$ & $\begin{array}{l}10.038^{* * *} \\
(3.371)\end{array}$ & $\begin{array}{l}10.829^{* * *} \\
(3.427)\end{array}$ & $\begin{array}{c}7.864^{* *} \\
(3.429)\end{array}$ & $\begin{array}{c}6.524^{*} \\
(3.481)\end{array}$ & $\begin{array}{c}1.373 \\
(3.466)\end{array}$ \\
\hline Tax revenue (in \% of GDP, t-i) & $\begin{array}{c}-0.459 \\
(0.294)\end{array}$ & $\begin{array}{c}-0.332 \\
(0.299)\end{array}$ & $\begin{array}{c}-1.070^{* * *} \\
(0.323)\end{array}$ & $\begin{array}{c}-0.988^{* * *} \\
(0.347)\end{array}$ & $\begin{array}{c}-1.082^{* * *} \\
(0.361)\end{array}$ & $\begin{array}{c}-0.986^{* * *} \\
(0.376)\end{array}$ & $\begin{array}{r}-0.683^{*} \\
(0.371)\end{array}$ & $\begin{array}{r}-0.614^{*} \\
(0.370)\end{array}$ \\
\hline GDP (t-i) & $\begin{array}{c}0.145^{*} \\
(0.086)\end{array}$ & $\begin{array}{c}0.211^{* *} \\
(0.092)\end{array}$ & $\begin{array}{c}0.202^{* *} \\
(0.087)\end{array}$ & $\begin{array}{c}0.198^{* *} \\
(0.096)\end{array}$ & $\begin{array}{c}0.209^{* *} \\
(0.101)\end{array}$ & $\begin{array}{c}0.165 \\
(0.108)\end{array}$ & $\begin{array}{c}0.139 \\
(0.122)\end{array}$ & $\begin{array}{c}0.127 \\
(0.125)\end{array}$ \\
\hline Right-wing parties (seat share, t-i) & $\begin{array}{c}0.014 \\
(0.012)\end{array}$ & $\begin{array}{c}0.012 \\
(0.013)\end{array}$ & $\begin{array}{c}0.008 \\
(0.013)\end{array}$ & $\begin{array}{c}0.003 \\
(0.014)\end{array}$ & $\begin{array}{c}-0.005 \\
(0.014)\end{array}$ & $\begin{array}{c}-0.012 \\
(0.015)\end{array}$ & $\begin{array}{c}-0.006 \\
(0.015)\end{array}$ & $\begin{array}{c}-0.013 \\
(0.016)\end{array}$ \\
\hline Old-age dependency ratio (t-i) & $\begin{array}{r}0.578^{*} \\
(0.310)\end{array}$ & $\begin{array}{c}0.137 \\
(0.346)\end{array}$ & $\begin{array}{c}-0.122 \\
(0.343)\end{array}$ & $\begin{array}{c}-0.320 \\
(0.392)\end{array}$ & $\begin{array}{c}-0.398 \\
(0.403)\end{array}$ & $\begin{array}{c}-0.612 \\
(0.453)\end{array}$ & $\begin{array}{c}-0.440 \\
(0.467)\end{array}$ & $\begin{array}{c}-0.792 \\
(0.506)\end{array}$ \\
\hline $\begin{array}{l}\text { Share of students enrolled } \\
\text { in private universities (t-i) }\end{array}$ & $\begin{array}{c}-0.089 \\
(0.081)\end{array}$ & $\begin{array}{c}-0.091 \\
(0.101)\end{array}$ & $\begin{array}{c}-0.092 \\
(0.080)\end{array}$ & $\begin{array}{r}-0.000 \\
(0.102)\end{array}$ & $\begin{array}{c}-0.058 \\
(0.085)\end{array}$ & $\begin{array}{c}0.068 \\
(0.104)\end{array}$ & $\begin{array}{c}0.002 \\
(0.087)\end{array}$ & $\begin{array}{c}0.092 \\
(0.101)\end{array}$ \\
\hline Constant & $\begin{array}{l}120.525^{\text {*** }} \\
(25.117)\end{array}$ & $\begin{array}{l}115.977^{* * *} \\
(26.115)\end{array}$ & $\begin{array}{l}138.987^{* * *} \\
(27.824)\end{array}$ & $\begin{array}{l}142.106^{* * *} \\
(30.692)\end{array}$ & $\begin{array}{l}108.571^{* * *} \\
(31.640)\end{array}$ & $\begin{array}{l}106.117^{* * *} \\
(34.128)\end{array}$ & $\begin{array}{l}81.730^{* * *} \\
(35.914)\end{array}$ & $\begin{array}{l}84.340^{* *} \\
(38.187)\end{array}$ \\
\hline Observations & 242 & 220 & 220 & 198 & 198 & 176 & 176 & 154 \\
\hline No. of countries & 22 & 22 & 22 & 22 & 22 & 22 & 22 & 22 \\
\hline $\log ($ likelihood) & -723.892 & -645.172 & -641.393 & -571.784 & -576.663 & -499.779 & -503.696 & -420.480 \\
\hline
\end{tabular}

\subsection{Causality issues}

There are two main concerns regarding the exogeneity of the share of international students in our regression. The first is pure reverse causality: Although the share of international students seems to induce changes in governmental policies in the private funding share of higher education, it seems equally plausible that private contributions induce changes 
in student migration patterns. Second, there may be unobserved factors that determine both private funding and the migration of students. Even though causality is difficult to establish in this aggregated context, it may be possible to rule out some concerns about the interdependence between student migration and the financing of higher education.

In the following section we propose two strategies to address these concerns regarding causality: First, we reverse the dependent and the independent variable and, additionally, include an indicator that captures quality differences between countries' higher education to test the effect of the private financing share (lagged by one year) on the share of international students. Second, we use an instrumental variable approach to deal with the likely endogeneity of the student immigration share.

\subsubsection{Reverse dependent variable and quality of higher education}

Let us, again, consider the statistically significant positive effect of the share of international students on the private financing share of higher education. With pure reverse causality, the positive coefficient in our estimation would indicate that international students are more likely to move to a country with higher tuition fees. If we assume that individuals maximize their utility, and hence, that the cost of education is an important determinant of the decision to study abroad, this reverse causality is not very likely to be the main causality channel (Beine et al. 2014). As a simple test of reverse causality, we run our baseline model again, but now regress the lagged private financing share on the share of international students. Our results are displayed in Model (22) in Table 4. The positive significant relationship between the private financing share and the share of international students persists. Hence, from a pure utility maximizing (i.e. cost-minimizing) point of view, it is not likely that a requirement of higher private contributions would attract more students to a given country. Similar results are found when using the share of non-discriminable students (Model (24)) and the share of discriminable students (Model (26)) as dependent variables. 
Table 4: Reverse dependent variable

\begin{tabular}{|c|c|c|c|c|c|c|}
\hline \multirow[t]{2}{*}{ DV: } & \multicolumn{2}{|c|}{$\begin{array}{l}\text { Share of } \\
\text { international students }\end{array}$} & \multicolumn{2}{|c|}{$\begin{array}{l}\text { Share of non-discriminable } \\
\text { international students }\end{array}$} & \multicolumn{2}{|c|}{$\begin{array}{l}\text { Share of discriminable } \\
\text { international students }\end{array}$} \\
\hline & $(22)$ & $(23)$ & $(24)$ & $(25)$ & $(26)$ & $(27)$ \\
\hline \multirow[t]{2}{*}{ Private expenditure share } & $0.111^{* * *}$ & $0.103^{* * *}$ & $0.027^{* *}$ & $0.030^{* *}$ & $0.095^{* * *}$ & $0.103^{* * *}$ \\
\hline & $(0.026)$ & $(0.024)$ & $(0.012)$ & $(0.014)$ & $(0.028)$ & $(0.027)$ \\
\hline \multirow[t]{2}{*}{ Employment rate tertiary educated } & $0.193^{*}$ & 0.004 & -0.067 & -0.024 & $0.364^{* * *}$ & 0.176 \\
\hline & $(0.111)$ & $(0.106)$ & $(0.052)$ & $(0.063)$ & $(0.122)$ & $(0.119)$ \\
\hline \multirow[t]{2}{*}{ Total expenditure share (in \% of GDP) } & $0.627^{* * *}$ & $0.236^{* *}$ & $0.076^{* *}$ & $0.124^{*}$ & $0.532^{* * *}$ & 0.077 \\
\hline & $(0.067)$ & $(0.114)$ & $(0.032)$ & $(0.067)$ & $(0.074)$ & $(0.127)$ \\
\hline \multirow[t]{2}{*}{ Tax revenue (in \% of GDP) } & $-0.321^{* * *}$ & $-0.235^{* *}$ & -0.020 & -0.022 & $-0.254^{* *}$ & $-0.200^{*}$ \\
\hline & $(0.110)$ & $(0.104)$ & $(0.052)$ & $(0.061)$ & $(0.121)$ & $(0.116)$ \\
\hline \multirow[t]{2}{*}{ GDP } & -0.029 & -0.013 & $-0.029^{*}$ & $-0.038^{*}$ & 0.002 & 0.037 \\
\hline & $(0.034)$ & $(0.038)$ & $(0.016)$ & $(0.022)$ & $(0.037)$ & $(0.042)$ \\
\hline \multirow[t]{2}{*}{ Right-wing parties (seat share) } & 0.004 & -0.000 & 0.002 & 0.000 & 0.002 & -0.001 \\
\hline & $(0.004)$ & $(0.004)$ & $(0.002)$ & $(0.003)$ & $(0.005)$ & $(0.005)$ \\
\hline \multirow[t]{2}{*}{ Old-age dependency ratio } & -0.069 & 0.097 & $0.141^{* *}$ & $0.158^{* *}$ & -0.154 & 0.099 \\
\hline & $(0.119)$ & $(0.132)$ & $(0.056)$ & $(0.078)$ & $(0.130)$ & $(0.148)$ \\
\hline Share of students enrolled & $0.110^{* * *}$ & $0.112^{* * *}$ & $0.083^{* * *}$ & $0.099^{* * *}$ & 0.045 & 0.065 \\
\hline in private universities & $(0.035)$ & $(0.040)$ & $(0.016)$ & $(0.024)$ & $(0.038)$ & $(0.045)$ \\
\hline \multirow{2}{*}{ Quality } & & 0.314 & & -0.240 & & $3.973^{* * *}$ \\
\hline & & $(0.842)$ & & $(0.496)$ & & $(0.938)$ \\
\hline \multirow[t]{2}{*}{ Constant } & -11.834 & 3.162 & 1.295 & -3.425 & $-25.624^{* *}$ & $-16.895^{*}$ \\
\hline & $(9.057)$ & $(8.970)$ & $(4.257)$ & $(5.281)$ & $(9.928)$ & $(9.994)$ \\
\hline Observations & 242 & 198 & 242 & 198 & 242 & 198 \\
\hline No. of countries & 22 & 22 & 22 & 22 & 22 & 22 \\
\hline $\log ($ likelihood $)$ & -485.900 & -351.896 & -303.196 & -246.996 & -508.133 & -373.303 \\
\hline
\end{tabular}

Notes: All variables are lagged by one year except the total expenditure for tertiary education in \% of GDP. Standard errors in parentheses; *** $\mathrm{p}<0.01,{ }^{* *} \mathrm{p}<0.05,{ }^{*} \mathrm{p}<0.1$. Variable description in Tables A.1 and A.2

However, one plausible interpretation as to why students might move to countries with high tuition fees is that private contributions can serve as a signal for quality ${ }^{11}$ To account for this, we follow Beine et al.'s (2014) method and use the average number of universities classified in the Shanghai Top 500 ranking for each country relative to the total number of students. The Shanghai ranking is based on a number of indicators, such as the number of scientific publications produced by the university, as well as how frequently these publications are cited. Although the criteria used for this ranking have been criticized, to our knowledge, this ranking system seems to be the most suitable one for our research. Models (23), (25) and (27) in Table 4 , show results with the quality control added. The coefficient of the private financing share remains positive and significant at the $1 \%$ and $5 \%$ level after controlling for quality differences between countries' higher education systems ${ }^{12}$ The coefficient of our quality indicator is only significant and positively correlated with the share of discriminable international students. One explanation may be that those students who, in many countries, have to pay comparatively high private contributions react more

\footnotetext{
${ }^{11}$ Beine et al. (2014) find support for not only a signalling effect, but also for a direct positive impact of fees on enrolment.

${ }^{12}$ We also included the quality variable in our preferred specifications (Models (6) and (7)). We still find a positive significant relationship between the share of international students and the private funding share.
} 
sensitively to changes in quality.

Another concern may be that students who move to countries that charge higher fees are only affected by part of the private contributions - on the one hand, because the private contributions may be partially publicly subsidized (e.g. through grants) and, on the other hand, because private spending not only encompasses household expenditures, but also expenditures of other private entities (e.g. private companies). We use the overall private financing share, as data on the private financing share net of subsidies or on household contributions are only available for a limited number of countries and years. For those countries and years for which we do have the more detailed information, we re-run our preferred specifications. Our results regarding the student immigration share remain qualitatively unchanged.13

\subsubsection{Instrumental variable approach}

As a second approach to find support for a causal effect of student immigration on the private funding share, we employ an instrumental variable estimation. Our choice of an instrument correlated with student immigration but not with the private funding share is based on the empirical migration choice literature, in which the importance of closeness has been proven to play an important role (see, e.g. Chiswick 1978). We construct two instruments based on linguistic and geographic closeness. Migration to a close country with closeness being in terms of either language or geography - is likely to be associated with lower costs than migration to a more distant country. Countries should therefore experience larger student immigration from geographically or linguistically close countries; however, there is no reason to expect that the closeness of countries will affect how host countries finance higher education. We use the CEPII online database (Mayer and Zignago 2011) to obtain the necessary data. For each host country $i$ in our sample, we observe the linguistic and geographic closeness, $d_{i j}$, to all possible home countries $j$ in the world. We multiply each closeness measure $d_{i j}$ by the overall population aged 25 to 64 in the respective home country $j$ in each year $t$, population $_{j t}$, in order to capture country size differences ${ }^{14}$ Note that in this population group most of the actual students should be

\footnotetext{
$\overline{13}$ In both specifications, the UK, which is characterized by both a high private share and by a large number of grants, is included in the sample. Results can be obtained on request.

${ }^{14}$ Full information is available for 160 possible home countries.
} 
excluded.$^{15}$ Both closeness measures are continuous and range from zero (the most distant) to one (the most close) ${ }^{16}$

For each host country in our sample and for each point in time, we then calculate the average of the population-weighted closeness measures for all possible home countries, producing our instrument:

$$
\mathrm{IV}_{i t}=\frac{1}{J} \sum_{j=1}^{J}\left(d_{i j} * \text { population }_{j t}\right) \quad \forall i=1, \ldots, 22 ; t=1, \ldots, 12 ; j=1, \ldots, 160
$$

As a further instrument, we re-do the calculations with the product of both closeness measures. This takes into account the fact that even though a potential host country may be quite far away, a similar language can partially compensate for that and vice versa. The first- and second-stage results from the instrumental variable estimations are reported in Table 5. As a robustness check, we run each model with and without the Anglo-Saxon countries.

Our estimates confirm the relevance of the instruments: They are clearly positively correlated with the share of international students as indicated by the high F-statistics of the instruments in the first stage (see the lower panel of Table 5).

The second-stage results are reported in the upper panel of Table 5 . The results show a statistically significant and positive effect of the instrumented share of international students on the private funding share of higher education. While the linguistic closeness IV is stronger for countries other than the Anglo-Saxon ones (Models (28) and (29)), the geographic closeness IV displays a comparatively larger effect in the full sample (Models (30) and (31)). Similar to our baseline fixed effects results, we find a negative and significant effect of our proxy variable for the stay rate, as well as a positive and significant effect of the share of older adults in the population. Interestingly, in the full sample models, the overall expenditure on higher education exerts a negative and significant effect on the private share of education funding. However, this effect seems to be driven by the

$\overline{15}$ We also ran our IV regressions with student-weighted closeness measures. Compared to the results in Table 5, the results remain qualitatively unchanged. However, weighting the distance measures with the number of students may violate the exclusion restriction as it may well capture the market for universities.

16 Geographic closeness is measured as the distance between the capital cities of the home and the host countries. We normalize this distance by relating it to the world's longest possible migration distance as the maximum; we also redefine this distance to obtain a continuous variable between zero (the most distant) and one (the most close). 
Anglo-Saxon countries, as this relationship becomes insignificant when these countries are excluded.

Table 5: Determinants of private higher education spending - instrumental variables

\begin{tabular}{|c|c|c|c|c|c|c|}
\hline & \multicolumn{2}{|c|}{ Linguistic } & \multicolumn{2}{|c|}{ Geographic } & \multicolumn{2}{|c|}{ Linguistic*Geographic } \\
\hline & Full sample & $\begin{array}{c}\text { Without } \\
\text { Anglo-Saxon }\end{array}$ & Full sample & $\begin{array}{c}\text { Without } \\
\text { Anglo-Saxon }\end{array}$ & Full sample & $\begin{array}{c}\text { Without } \\
\text { Anglo-Saxon }\end{array}$ \\
\hline & $(28)$ & $(29)$ & $(30)$ & $(31)$ & $(32)$ & $(33)$ \\
\hline \multicolumn{7}{|c|}{ Second stage results (Dependent variable: Private financing share): } \\
\hline Share of international students & $1.096^{* * *}$ & $1.240^{* * *}$ & $1.891^{* * *}$ & $1.288^{* * *}$ & $1.743^{* * *}$ & $1.181^{* *}$ \\
\hline (Instruments) & $(0.247)$ & $(0.465)$ & $(0.475)$ & $(0.473)$ & $(0.396)$ & $(0.475)$ \\
\hline \multirow[t]{2}{*}{ Employment rate tertiary educated } & $-1.251^{* * *}$ & $-0.860^{* * *}$ & $-1.310^{* * *}$ & $-0.857^{* * *}$ & $-1.299^{* * *}$ & $-0.864^{* * *}$ \\
\hline & $(0.259)$ & $(0.209)$ & $(0.302)$ & $(0.209)$ & $(0.291)$ & $(0.208)$ \\
\hline \multirow[t]{2}{*}{ Total expenditure (in \% of GDP) } & -0.360 & 0.192 & $-0.852^{* *}$ & 0.184 & $-0.760^{* *}$ & 0.201 \\
\hline & $(0.234)$ & $(0.196)$ & $(0.359)$ & $(0.197)$ & $(0.316)$ & $(0.196)$ \\
\hline \multirow[t]{2}{*}{ Tax revenue (in \% of GDP) } & 0.110 & 0.193 & 0.249 & 0.204 & 0.223 & 0.180 \\
\hline & $(0.285)$ & $(0.248)$ & $(0.336)$ & $(0.249)$ & $(0.323)$ & $(0.248)$ \\
\hline \multirow[t]{2}{*}{ GDP } & 0.126 & -0.099 & 0.123 & -0.106 & 0.123 & -0.091 \\
\hline & $(0.080)$ & $(0.228)$ & $(0.093)$ & $(0.229)$ & $(0.090)$ & $(0.228)$ \\
\hline \multirow[t]{2}{*}{ Right-wing parties (seat share) } & 0.004 & 0.001 & 0.001 & 0.001 & 0.002 & 0.001 \\
\hline & $(0.011)$ & $(0.010)$ & $(0.013)$ & $(0.010)$ & $(0.013)$ & $(0.010)$ \\
\hline \multirow[t]{2}{*}{ Old-age dependency ratio } & $0.595^{* *}$ & $0.694^{* *}$ & 0.480 & $0.685^{* *}$ & 0.502 & $0.706^{* *}$ \\
\hline & $(0.282)$ & $(0.279)$ & $(0.331)$ & $(0.280)$ & $(0.318)$ & $(0.278)$ \\
\hline \multirow{2}{*}{$\begin{array}{l}\text { Share of students enrolled } \\
\text { in private universities }\end{array}$} & -0.095 & -0.073 & $-0.182^{*}$ & -0.076 & $-0.166^{*}$ & -0.068 \\
\hline & $(0.082)$ & $(0.065)$ & $(0.103)$ & $(0.065)$ & $(0.097)$ & $(0.065)$ \\
\hline \multicolumn{7}{|c|}{ First stage results (Dependent variable: Share of international students): } \\
\hline \multirow[t]{2}{*}{ IV: Closeness } & $0.995^{* * *}$ & $0.468^{* * *}$ & $0.172^{* * *}$ & $0.126^{* * *}$ & $0.941^{* * *}$ & $0.584^{* * *}$ \\
\hline & $(0.096)$ & $(0.054)$ & $(0.031)$ & $(0.015)$ & $(0.145)$ & $(0.070)$ \\
\hline \multirow[t]{2}{*}{ Employment rate tertiary educated } & 0.085 & -0.033 & 0.171 & 0.032 & 0.119 & -0.051 \\
\hline & $(0.102)$ & $(0.052)$ & $(0.117)$ & $(0.053)$ & $(0.113)$ & $(0.052)$ \\
\hline \multirow[t]{2}{*}{ Total expenditure (in \% of GDP) } & $0.382^{* * *}$ & $0.086^{*}$ & $0.498^{* * *}$ & 0.057 & $0.504^{* * *}$ & $0.093^{* *}$ \\
\hline & $(0.073)$ & $(0.046)$ & $(0.082)$ & $(0.047)$ & $(0.079)$ & $(0.046)$ \\
\hline \multirow[t]{2}{*}{ Tax revenue (in \% of GDP) } & $0.200^{*}$ & -0.087 & 0.032 & -0.061 & 0.045 & $-0.099^{*}$ \\
\hline & $(0.116)$ & $(0.058)$ & $(0.131)$ & $(0.060)$ & $(0.127)$ & $(0.059)$ \\
\hline \multirow[t]{2}{*}{ GDP } & $-0.133^{* * *}$ & -0.083 & -0.058 & $-0.110^{*}$ & $-0.083^{* *}$ & -0.049 \\
\hline & $(0.034)$ & $(0.060)$ & $(0.038)$ & $(0.062)$ & $(0.038)$ & $(0.060)$ \\
\hline \multirow[t]{2}{*}{ Right-wing parties (seat share) } & -0.000 & $0.005^{* *}$ & -0.001 & 0.003 & 0.000 & $0.005^{* *}$ \\
\hline & $(0.004)$ & $(0.002)$ & $(0.005)$ & $(0.002)$ & $(0.005)$ & $(0.002)$ \\
\hline \multirow[t]{2}{*}{ Old-age dependency ratio } & -0.004 & $0.235^{* * *}$ & -0.172 & $0.122^{*}$ & 0.058 & $0.235^{* * *}$ \\
\hline & $(0.111)$ & $(0.066)$ & $(0.137)$ & $(0.067)$ & $(0.122)$ & $(0.066)$ \\
\hline Share of students enrolled & 0.009 & $0.041^{* * *}$ & 0.026 & $0.027^{*}$ & 0.043 & $0.042^{* * *}$ \\
\hline in private universities & $(0.032)$ & $(0.014)$ & $(0.038)$ & $(0.015)$ & $(0.035)$ & $(0.014)$ \\
\hline Observations & 264 & 204 & 264 & 204 & 264 & 204 \\
\hline No. of countries & 22 & 17 & 22 & 17 & 22 & 17 \\
\hline $\log ($ likelihood $)$ & -800.939 & -538.304 & -839.486 & -538.894 & -830.946 & -537.617 \\
\hline F-statistic of excluded instrument & 106.63 & 74.35 & 29.83 & 71.27 & 42.08 & 69.23 \\
\hline Durbin-Wu-Hausman $\chi^{2}$ test & 8.08 & 3.21 & 9.20 & 3.48 & 10.97 & 2.52 \\
\hline p-value & $(0.426)$ & $(0.921)$ & $(0.326)$ & $(0.901)$ & $(0.204)$ & $(0.961)$ \\
\hline
\end{tabular}

Notes: All variables are lagged by one year except the total expenditure for tertiary education in \% of GDP. Standard errors in parentheses; ${ }^{* * *} \mathrm{p}<0.01,{ }^{* *} \mathrm{p}<0.05,{ }^{*} \mathrm{p}<0.1$. Variable description in Tables A.1 and A.2

Our results point toward an overall downward bias in the OLS estimates of the effects of student immigration on the private financing share of higher education. This may be a result of the fact that the two plausible causality channels are at work at the same time: First, student migration may induce changes in governmental policies towards more private financing - this is the channel focused on in the preceding analysis. However, according to the second possible causality channel, a higher share of private contributions may also 
induce fewer students to come. A positive but smaller coefficient in the OLS estimations, compared to the IV estimations indicates that both countervailing effects are present, with the former positive effect dominating the latter negative effect. After isolating the first causality channel by using an instrument, the coefficient of student immigration should indeed be larger.

To assess the significance of the difference between the IV coefficients with the OLS coefficients, we run Durbin-Wu-Hausman $\chi^{2}$ tests. The differences are not statistically significant for either specification. Given the results of our IV estimations and the respective Durbin-Wu-Hausman $\chi^{2}$ tests, we can cautiously interpret our OLS estimates to represent a positive causal effect of student immigration on the private share of higher education financing.

\section{Conclusion}

In this paper, we have analysed whether and how student migration affects governments' decisions about how to finance higher education. Theoretical research suggests that, in higher education systems that are partly tax funded, a country's labour force might not be willing to subsidize the education of international students who might move away after graduation. Increasing student migration and a comparably low stay rate of graduates may thus lead to a larger share of private contributions if a government aims to make the financing of higher education more sustainable.

We estimate the effect of the student immigration share on the private financing share of higher education based on aggregated data from 22 OECD countries, for the period of 2000 to 2011. Since there are various additional factors that may determine the financing of higher education, we also include fiscal, political, and institutional determinants. We find that the larger the share of international students among all students in a country, the more a country shifts to private-based funding. This result is robust to changes in the specifications such as estimations for country groups, expanded lag structures and the use of an IV approach. As countries have the possibility to charge different fees for certain groups of international students, we also re-ran our regressions, splitting the share of international students into those who can and those who cannot be treated differently with regard to fees. We find the effect of the share of international students who can be charged higher tuition fees to be driven by the Anglo-Saxon countries. In contrast, in 
the other countries in our sample, the share of non-discriminable international students is important.

With this study, we want to highlight the importance of the need for more empirical research on the question how, in general, mobility affects policy choice. For the case of student immigration, we have studied its impact on countries' political decisions as how to finance higher education. We recommend that further research in this area should not only focus on the determinants of student migration, but also on the fiscal consequences that may result from this 17 A possible next step that would complement our analysis could be to study the determinants of the private financing share using micro-level data. Not only would this potentially permit the use of more control variables, but also to include exact data on the amount of tuition fees paid by different student groups, data on the number of international graduates who stay and work in their host country, and data on grants and scholarships.

\footnotetext{
$\overline{17}$ For a discussion of possible policy instruments to correct for the underprovision of higher education as a result of student or graduate migration, see, e.g. Gérard and Uebelmesser (2014) and the literature cited therein.
} 


\section{Literature}

Armingeon, K.; L. Knöpfel; D. Weisstanner and S. Engler (2014): Comparative Political Data Set III 1990-2012. Bern: Institute of Political Science, University of Berne.

Beine, M.; R. Noël and L. Ragot (2014): Determinants of the international mobility of students, Economics of Education Review 41, 40-54.

Boix, C. (1997): Political parties and the supply side of the economy: The provision of physical and human capital in advanced economies, 1960-1990, American Journal of Political Science 41(3), 814-845.

Bratsberg, B. (1995): The incidence of non-return among foreign students in the United States, Economics of Education Review 14(4), 373-384.

Bruckmeier, K.; G.B. Fischer and B.U. Wigger (2013): Does distance matter? Tuition fees and enrollment of first-year students at German public universities, CESifo Working Paper 4258, Munich: CESifo.

Busemeyer, M.R. (2007): Determinants of public education spending in 21 OECD democracies, 1980-2001, Journal of European Public Policy 14(4), 582-610.

Busemeyer, M.R. (2009): Social democrats and the new partisan politics of public investment in education, Journal of European Public Policy 16(1), 107-126.

Chiswick, B. (1978): The effect of Americanization on the earnings of foreign born men, Journal of Political Economy 86, 897-922.

Demange, G.; R. Fenge and S. Uebelmesser (2014): Financing higher education in a mobile world, Journal of Public Economic Theory 16, 343-371.

Docquier, F. and A. Marfouk (2006): International migration by educational attainment (1990-2000) - Release 1.1. In: Ozden, C. and M. Schiff (eds), International Migration, Remittances and Development, Palgrave Macmillan: New York.

Dreher, A. and P. Poutvaara (2011): Foreign students and migration to the United States, World Development 39(8), 1294-1307.

Dwenger, N.; J. Storck and K. Wrohlich (2012): Do tuition fees affect the mobility of university applicants? Evidence from a natural experiment, Economics of Education Review 31, 155-167. 
European Commission (2012a): Report reveals wide fluctuations in cost of higher education and support for students.

http://europa.eu/rapid/press-release_IP-12-947_en.htm

European Commission (2012b): Austria and Belgium given more time to justify quotas. http://europa.eu/rapid/press-release_IP-12-1388_en.htm

Felbermayr G.J. and I. Reczkowski (2014): International student mobility and high-skilled migration: the evidence, In: M. Gérard and S. Uebelmesser (eds.): From mobility of students to mobility of the highly skilled: implications for fiscal and economic policy, CESifo Seminar Series, MIT Press, Cambr., MA, 15-56.

Gérard, M. (2007): Financing Bologna: Which country will pay for foreign students?, Education Economics 15(4), 441-454.

Gérard, M. and S. Uebelmesser (2014): Financing higher education when students and graduates are internationally mobile, In: M. Gérard and S. Uebelmesser (eds.): From mobility of students to mobility of the highly skilled: implications for fiscal and economic policy, CESifo Seminar Series, MIT Press, Cambr., MA, 145-188.

Hübner, M. (2012): Do tuition fees affect enrollment behavior? Evidence from a 'natural experiment' in Germany, Economics of Education Review 31, 949-960.

Kauder, B. and N. Potrafke (2013): Government ideology and tuition fee policy: Evidence from the German States, CESifo Economic Studies 59(4), 628-649.

Ladd, H.F. and S.E. Murray (2001): Intergenerational conflict reconsidered: County demographic structure and the demand for public education, Economics of Education Review 20, 343-357.

Mayer, T. and S. Zignago (2011): Notes on CEPII's distances measures: The GeoDist database, CEPII Working Paper 2011- 25, CEPII.

OECD (2001-2014): Education at a Glance. OECD Indicators, Paris: OECD.

Parey, M. and F. Waldinger (2011): Studying abroad and the effect on international labor market mobility: evidence from the introduction of Erasmus, The Economic Journal 121, 194-222.

Poterba, J.M. (1998): Demographic change, intergenerational linkages, and public education, The American Economic Review 88(2), 315-320. 
Potrafke, N. (2011a): Does government ideology influence budget composition? Empirical evidence from OECD countries, Economics of Governance 12(2), 101-134.

Potrafke, N. (2011b): Public expenditures on education and cultural affairs in the West German states: Does government ideology influence the budget composition?, German Economic Review 12(1), 124-145.

Rosenzweig, M. (2008): Higher education and international migration in Asia: brain circulation, Annual World Bank Conference on Development Economics (Beijing), 59-100.

Tandberg, D.A. (2010): Politics, interest groups and state funding of public higher education, Research in Higher Education 51, 416-450. 


\section{Appendix}

Table A.1: Definitions and sources of variables

\begin{tabular}{|c|c|c|c|c|}
\hline Variable & Description & Source & Year & Remark \\
\hline $\begin{array}{l}\text { Private funding share } \\
\text { of higher education }\end{array}$ & $\begin{array}{l}\text { Private share of expenditure for tertiary educa- } \\
\text { tion among total expenditure. }\end{array}$ & $\begin{array}{l}\text { OECD Education } \\
\text { at a Glance }\end{array}$ & $2000-2011$ & $\begin{array}{l}\text { Linear interpolation: Norway } 2004 \\
\text { and } 2005 \text {; Values for New Zealand of } \\
\text { year } 2002 \text { taken for } 2001 \text {; Value for } \\
\text { Germany of } 2009 \text { taken for } 2010 \text {. }\end{array}$ \\
\hline $\begin{array}{l}\text { Share of international } \\
\text { students }\end{array}$ & $\begin{array}{l}\text { Net share of non citizen students among all stu- } \\
\text { dents in a country. }\end{array}$ & $\begin{array}{l}\text { OECD Education } \\
\text { at a Glance }\end{array}$ & $1999-2011$ & $\begin{array}{l}\text { Value of Portugal for } 2002 \text { is taken } \\
\text { from the UNESCO, value of } 2001 \text { is } \\
\text { created by linear interpolation. }\end{array}$ \\
\hline $\begin{array}{l}\text { Share of non- } \\
\text { discriminable in- } \\
\text { ternational students }\end{array}$ & $\begin{array}{l}\text { Share of international students that canot be } \\
\text { discriminated against (that pay the same amount } \\
\text { of tuition fees like domestic students) }\end{array}$ & $\begin{array}{l}\text { OECD Education } \\
\text { at a Glance }\end{array}$ & $2000-2011$ & \\
\hline $\begin{array}{l}\text { Share of discriminable } \\
\text { international students }\end{array}$ & $\begin{array}{l}\text { Share of international students that can be dis- } \\
\text { criminated against (that can legally be asked to } \\
\text { pay higher tuition fees than domestic students) }\end{array}$ & $\begin{array}{l}\text { OECD Education } \\
\text { at a Glance }\end{array}$ & $2000-2011$ & \\
\hline $\begin{array}{l}\text { Employment rate ter- } \\
\text { tiary educated (Stay } \\
\text { rate proxy) }\end{array}$ & $\begin{array}{l}\text { Number of } 25-64 \text { year-old tertiary educated in } \\
\text { employment as a percentage of the population } \\
\text { aged } 25 \text { to } 64\end{array}$ & OECD & $1999-2011$ & \\
\hline $\begin{array}{l}\text { Total expenditure } \\
(* 10, \text { in } \% \text { of GDP })\end{array}$ & $\begin{array}{l}\text { Public and private expenditure for tertiary edu- } \\
\text { cation per student (\$US, PPP, current) in \% of } \\
\text { GDP. }\end{array}$ & $\begin{array}{l}\text { OECD Education } \\
\text { at a Glance }\end{array}$ & $2000-2011$ & $\begin{array}{l}\text { Linear interpolation: Denmark, Ice- } \\
\text { land and Japan 2003, Norway 2004 } \\
\text { and Slovak Republic } 2002 \text { and 2003; } \\
\text { Germany } 2010 .\end{array}$ \\
\hline Tax revenue & $\begin{array}{l}\text { Tax revenue (excl. social security funds) in \% } \\
\text { of GDP. }\end{array}$ & OECD & 1999-2011 & \\
\hline $\operatorname{GDP}(/ 100,000)$ & $\begin{array}{l}\text { Annual gross domestic product (\$US, PPP, cur- } \\
\text { rent, in } 1.0000 \$ \mathrm{US} \text { ). }\end{array}$ & OECD & 1999-2011 & \\
\hline $\begin{array}{ll}\text { Students } & \text { enrolled in } \\
\text { private } & \text { universities } \\
\text { (share) } & \end{array}$ & $\begin{array}{l}\text { Share of students enrolled in independent private } \\
\text { universities (institution that is controlled and } \\
\text { managed by a non-governmental, private entity) } \\
\text { among all students enrolled in a country. }\end{array}$ & OECD & 1999-2011 & \\
\hline $\begin{array}{l}\text { Right-wing parties } \\
\text { (seat share) }\end{array}$ & $\begin{array}{l}\text { Right-wing parties as a percentage of parliamen- } \\
\text { tary seats of all governmental parties, weighted } \\
\text { by the number of days the government was in } \\
\text { office in a given year. }\end{array}$ & $\begin{array}{l}\text { Armington et al. } \\
(2012)\end{array}$ & $1999-2011$ & \\
\hline $\begin{array}{l}\text { Old-age dependency } \\
\text { ratio }\end{array}$ & $\begin{array}{l}\text { Number of individuals older than } 65 \text { relative to } \\
\text { the individuals aged } 20 \text { to } 64 \text {. }\end{array}$ & OECD & 1999-2011 & \\
\hline Quality & $\begin{array}{l}\text { Number of universities classified in the Shanghai } \\
\text { top } 500 \text { ranking relative to the total number of } \\
\text { students in a country. }\end{array}$ & $\begin{array}{l}\text { Shanghai ranking, } \\
\text { OECD }\end{array}$ & 2003-2011 & \\
\hline IV Linguistic closeness & $\begin{array}{l}\text { For each host country average of the population- } \\
\text { weighted linguistic closeness measures for all } \\
\text { possible home countries }\end{array}$ & CEPII, OECD & $1999-2011$ & \\
\hline $\begin{array}{l}\text { IV Geographic close- } \\
\text { ness }\end{array}$ & $\begin{array}{l}\text { For each host country average of the population- } \\
\text { weighted geographic closeness measures for all } \\
\text { possible home countries }\end{array}$ & CEPII, OECD & 1999-2011 & \\
\hline
\end{tabular}

Iceland, Ireland, Italy, Japan, Netherlands, New Zealand, Norway, Poland, Portugal, Slovak Republic, Spain, Sweden, United Kingdom, United States 
Table A.2: Summary statistics

\begin{tabular}{|c|c|c|c|c|c|c|}
\hline Variable & & Mean & Std. Dev. & Min & $\operatorname{Max}$ & Observations \\
\hline \multirow[t]{3}{*}{ Private expenditure share } & overall & 23.86 & 18.63 & 2.11 & 74.78 & $\mathrm{~N}=264$ \\
\hline & between & & 18.19 & 3.44 & 63.35 & $\mathrm{n}=22$ \\
\hline & within & & 5.49 & 5.01 & 51.77 & $\mathrm{~T}=12$ \\
\hline \multirow[t]{3}{*}{ Share of international students } & overall & 7.85 & 6.35 & 0.38 & 28.91 & $\mathrm{~N}=264$ \\
\hline & between & & 5.88 & 0.58 & 20.98 & $\mathrm{n}=22$ \\
\hline & within & & 2.68 & -8.36 & 15.78 & $\mathrm{~T}=12$ \\
\hline \multirow[t]{3}{*}{ Share of non-discriminable international students } & overall & 2.13 & 2.29 & 0.00 & 12.47 & $\mathrm{~N}=264$ \\
\hline & between & & 2.07 & 0.00 & 8.76 & $\mathrm{n}=22$ \\
\hline & within & & 1.05 & -0.85 & 5.83 & $\mathrm{~T}=12$ \\
\hline \multirow[t]{3}{*}{ Share of discriminable international students } & overall & 5.72 & 5.68 & 0.37 & 27.24 & $\mathrm{~N}=264$ \\
\hline & between & & 5.28 & 0.51 & 19.78 & $\mathrm{n}=22$ \\
\hline & within & & 2.35 & -9.19 & 13.28 & $\mathrm{~T}=12$ \\
\hline \multirow[t]{3}{*}{ Employment rate tertiary educated } & overall & 85.02 & 3.14 & 77.13 & 95.45 & $\mathrm{~N}=264$ \\
\hline & between & & 2.85 & 79.57 & 92.06 & $\mathrm{n}=22$ \\
\hline & within & & 1.44 & 79.87 & 88.85 & $\mathrm{~T}=12$ \\
\hline \multirow[t]{3}{*}{ Total expenditure $(* 10$, in $\%$ of GDP $)$} & overall & 1.41 & 0.39 & 0.78 & 3.11 & $\mathrm{~N}=264$ \\
\hline & between & & 0.37 & 0.94 & 2.71 & $\mathrm{n}=22$ \\
\hline & within & & 0.13 & 0.86 & 1.80 & $\mathrm{~T}=12$ \\
\hline \multirow[t]{3}{*}{ Tax revenue (in \% of GDP) } & overall & 26.52 & 6.90 & 15.55 & 48.43 & $\mathrm{~N}=264$ \\
\hline & between & & 6.93 & 16.79 & 46.17 & $\mathrm{n}=22$ \\
\hline & within & & 1.22 & 22.83 & 30.91 & $\mathrm{~T}=12$ \\
\hline \multirow[t]{3}{*}{ GDP $(/ 100,000)$} & overall & 14.23 & 27.66 & 0.08 & 155.18 & $\mathrm{~N}=264$ \\
\hline & between & & 27.94 & 0.11 & 130.60 & $\mathrm{n}=22$ \\
\hline & within & & 4.15 & -13.52 & 38.81 & $\mathrm{~T}=12$ \\
\hline Share of students enrolled & overall & 24.93 & 28.44 & 0.16 & 100.00 & $\mathrm{~N}=264$ \\
\hline \multirow[t]{2}{*}{ in private universities } & between & & 29.03 & 1.25 & 100.00 & $\mathrm{n}=22$ \\
\hline & within & & 3.84 & 2.32 & 37.22 & $\mathrm{~T}=12$ \\
\hline \multirow[t]{3}{*}{ Right-wing parties (seat share) } & overall & 43.37 & 39.71 & 0.00 & 100.00 & $\mathrm{~N}=264$ \\
\hline & between & & 25.85 & 0.00 & 91.09 & $\mathrm{n}=22$ \\
\hline & within & & 30.61 & -31.80 & 129.85 & $\mathrm{~T}=12$ \\
\hline \multirow[t]{3}{*}{ Old-age dependency ratio } & overall & 25.33 & 4.59 & 16.36 & 39.53 & $\mathrm{~N}=264$ \\
\hline & between & & 4.49 & 18.27 & 33.93 & $\mathrm{n}=22$ \\
\hline & within & & 1.32 & 19.34 & 30.93 & $\mathrm{~T}=12$ \\
\hline \multirow[t]{3}{*}{ Quality } & overall & 1.25 & 0.77 & 0.00 & 2.77 & $\mathrm{~N}=198$ \\
\hline & between & & 0.78 & 0.00 & 2.52 & $\mathrm{n}=22$ \\
\hline & within & & 0.14 & 0.62 & 1.78 & $\mathrm{~T}=9$ \\
\hline \multirow[t]{3}{*}{ IV Linguistic closeness } & overall & 21.86 & 7.94 & 5.06 & 44.88 & $\mathrm{~N}=242$ \\
\hline & between & & 7.45 & 7.46 & 36.75 & $\mathrm{n}=22$ \\
\hline & within & & 3.15 & 13.86 & 29.99 & $\mathrm{~T}=11$ \\
\hline \multirow[t]{3}{*}{ IV Geographic closeness } & overall & 89.21 & 21.79 & 32.14 & 127.49 & $\mathrm{~N}=242$ \\
\hline & between & & 14.88 & 47.41 & 98.65 & $\mathrm{n}=22$ \\
\hline & within & & 16.21 & 61.04 & 118.05 & $\mathrm{~T}=11$ \\
\hline \multirow[t]{3}{*}{ IV Linguistic*Geographic closeness } & overall & 14.22 & 5.10 & 2.82 & 31.66 & $\mathrm{~N}=242$ \\
\hline & between & & 4.82 & 4.50 & 26.17 & $\mathrm{n}=22$ \\
\hline & within & & 1.92 & 8.77 & 19.71 & $\mathrm{~T}=11$ \\
\hline
\end{tabular}

